ORIGINAL ARTICLE

\title{
Spirulina platensis extract addition to semen extender enhances cryotolerance and fertilizing potentials of buffalo bull spermatozoa
}

\author{
Magdy Badr ${ }^{1}$ Zaher Rawash¹, Ahmed Azab², Ragab Dohreg1 , Taha Ghattas³, Mohamed Fathi ${ }^{4 *}$ (D) \\ ${ }^{1}$ Artificial Insemination and Embryo Transfer Department, Animal Reproduction Research Institute, Giza, Egypt \\ 2Pathology Department, Animal Reproduction Research Institute, Giza, Egypt \\ ${ }^{3}$ Biology of Reproduction Department, Animal Reproduction Research Institute, Giza, Egypt \\ ${ }^{4}$ Department of Theriogenology, Faculty of Veterinary Medicine, Cairo University, Giza, Egypt
}

How to cite: Badr M, Rawash Z, Azab A, Dohreg R, Ghattas T, Fathi M. Spirulina platensis extract addition to semen extender enhances cryotolerance and fertilizing potentials of buffalo bull spermatozoa. Anim Reprod. 2021;18(2):e20200520. https://doi.org/10.1590/1984-3143-AR2020-0520

\begin{abstract}
The objective of this study was to investigate the effect of Spirulina platensis extract (SPE) addition to the freezing extender on freezability, lipid peroxidation, ultrastructure alterations and fertilizing potentials of frozen-thawed buffalo bull spermatozoa. Semen samples were collected with artificial vagina from five adult fertile bulls and diluted with Tris-base extender containing SPE $(1,5,10$ and $20 \mu \mathrm{g} / \mathrm{mL})$ or without SPE (control). Diluted semen was cooled to $4{ }^{\circ} \mathrm{C}$ throughout one hour and frozen in $0.25 \mathrm{~mL}$ straws: prior to being stored in liquid nitrogen. Cryopresreved spermatozoa were assessed for post-thawing sperm motility, viability, acrosomal integrity, ultrastructure changes, antioxidant activities, lipid peroxidation and fertility rate. The current results clearly indicated that adding $10 \mu \mathrm{g} / \mathrm{mL}$ SPE to the freezing extender significantly improved $(\mathrm{P}<0.05)$ post-thawing motility and decrease the percentage of acrosomal damage $(51.67 \pm 6.02 \%$ and $16.33 \pm 1.46 \%$, respectively) compared with the control $(28.33 \pm 4.41 \%$ and $26.33 \pm 1.77 \%$, respectively). Moreover, addition of $10 \mu \mathrm{g} / \mathrm{mL}$ SPE to the semen extender significantly diminished $(P<0.05)$ MDA concentration $\left(10.66 \pm 2.40 \mathrm{nmol} / 10^{9}\right)$ compared with the control $\left(22.66 \pm 4.26 \mathrm{nmol} / 10^{9}\right)$. Therefore, the present results revealed that addition of $10 \mu \mathrm{gl} / \mathrm{mL}$ SPE to the freezing extender might improve semen quality and reduce cryodamage of the buffalo bull spermatozoa.
\end{abstract}

Keywords: spirulina, buffalo bull, spermatozoa, cryopreservation, lipid peroxidation.

\section{Introduction}

Semen cryopreservation offers many benefits to the livestock productiveness through dissemination of valuable genetic material by means of artificial insemination (Bucak et al., 2009). Achievement of any successful Al program depends on the proper management of semen collection, storage and handling (Leboeuf et al., 2000). Various conception rates were recorded in buffaloes; 33.3\% during breeding season (Paul and Prakash, 2005) and 28.2\% out of the breeding season (Baruselli et al., 2007). Although, many protocols have been developed for semen cryopreservation, sperm cryo-survival rates were still not optimum in buffalo. Cryopreservation induces some irreversible damages in sperm cells (Medeiros et al., 2002). One of the most vital factors responsible for these damages is the unregulated increase of reactive oxygen species (ROS), which can lead to oxidative stress (Vemo et al., 2018). Oxidative stress (OS), occurs mainly as result of imbalance between the reactive oxygen species (ROS) and antioxidants capacity (El-Tohamy and El-Nattat, 2010). Oxidative

*Corresponding author: mido2022@yahoo.com

Received: October 6, 2020. Accepted: July 5, 2021

Financial support: None.

Conflicts of interest: The authors have no conflict of interest to declare.

(c) (i) Copyright (c) The Author(s). This is an Open Access article distributed under the terms of the Creative Commons Attribution License, which C. 
stress induces damage to sperm by increasing lipid peroxidation rate and altering membrane function manifested with impaired metabolism, morphology, mobility and fertilizing potential, ROS is usually derived from three sources; mitochondria of sperm cells, plasma membrane and L- amino acid oxidases activity (Aitken, 2017). Balance between ROS production and their detoxification is an important factor for sperm survival and function before, during and after cryopreservation. Moreover, ROS are associated with lipid peroxidation, DNA and protein damages (Farber et al., 1990; Calamera et al., 2001; Neild et al., 2003), affecting the final usefulness of the cryopreserved semen. Lipid peroxidation leads to decreasing life span of spermatozoa either in vivo or after artificial insemination (Alvarez and Storey, 1982). Antioxidant molecules could not only reduce the impact of OS but also controlling physiological sperm functions (Aitken et al., 2004; Ford, 2004).

In order to counteract the deleterious effects of ROS, plants with antioxidant properties such as green tea extracts (Venkatachalam et al., 2012; Abshenas et al., 2011) and ethanolic extracts of Bersama engleriana (Vemo et al., 2017) had been used.

Spirulina is a planktonic blue green algae that considered as a traditional food of some Mexican and African people due to its enrichment with many valuable nutrients (Khan et al., 2005). Spirulina is considered as a strong natural antioxidant with anti-lipid peroxidation activity (Kurd and Samavati, 2015). In addition, Spirulina contains both enzymatic (superoxide dismutase, glutathione peroxidase, catalase and ascorbate peroxidase) and non-enzymatic (carotenoids, ascorbic acid, tocopherols and chlorophy-ll derivatives) as antioxidant protection system (Abd El-Baky et al., 2007). The positive effect of Spirulina was previously reported in swine sperm quality in terms of concentration, motility and post-storage viability (Granaci, 2007a). Also, Mizera et al., 2019 concluded that addition of spirulina to semen extender improves the bovine semen quality. In the same way Kistanova et al. (2009) reported that supplementation of diet with spirulina extract improves boar semen characteristics.

In rats, Nah et al. (2012) demonstrated that spirulina extracts had both antioxidant activity and anti-inflamatory action, in rabbits (El-Ratel and Gabr, 2020; Fouda and Ismail, 2017) concluded that addition of spirulina could improve rabbit semen production and its antioxidant potential. C-phycocyanin (C-PC) is considered an extracted biocompound from Arthrospira maxima with an antioxidant property, its addition to swine semen extender resulted in an increase of progressive motility and decrease of the intracellular ROS production (Antonio Marcos et al., 2018).

Despite all these, studies related to the effects of Spirulina on male reproduction were still limited. So, the current study aimed to investigate the effect of supplementation of buffalo bull semen extender with the hydro-ethanolic extract of Spirulina on the freezability, biochemical characteristics and fertilizing potentials of buffalo bull spermatozoa.

\section{Material and methods}

\section{Spirulina Platensis Extract (SPE)}

Spirulina was obtained from national research institute, algae biotechnology department, Egypt.

Dried Spirulina was extracted by soxhletation. The Spirulina powder (20g) was soaked in $1 \mathrm{~L}$ of ultrapure water and shaken continuously for $24 \mathrm{~h}$ at room temperature. The mixture was then centrifuged at $5000 \mathrm{~g}$ for $10 \mathrm{~min}$ and the supernatant was filtered to remove the cell debris. The sample was then freeze-dried and the dried extract was stored at $4{ }^{\circ} \mathrm{C}$ till use (Chu et al., 2010). 


\section{Extender preparation}

All reagents and chemicals were obtained from Sigma-Aldrich.

The cryoprotective extender was Tris-based extender (375 mM Tris; $124 \mathrm{mM}$ citric acid; $41.6 \mathrm{mM}$ glucose, 20\% (v/v) egg yolk, 7\% (v/v) glycerol, $25 \mathrm{mg}$ gentamicin, and 50,000 IU penicillin; and dissolved in $100 \mathrm{~mL}$ deionized water, $\mathrm{pH}=6.8$ ), Spirulina platensis extract (SPE) was added to the extender with different concentrations; $1,5,10$ and $20 \mu \mathrm{g} / \mathrm{mL}$ or extender SPE free (control).

\section{Semen collection}

Semen samples were collected from five healthy buffalo bulls aging 3-4 years and housed individually in pens at Animal Reproduction Research Institute farm (Cairo, Egypt). Two consecutive ejaculates were collected from each bull weekly for six weeks using an artificial vagina. The ejaculates were pooled to eliminate variability between the collected samples. Semen samples were assessed for volume, sperm concentration, percentage of motile spermatozoa and sperm morphology. The ejaculates with at least 70\% progressive forward motility and $85 \%$ normal sperm morphology were used. All experiments were done with at least 3 replicates for each group. Animal care standards were followed and licensed by Animal Use Ethical Committee at Reproduction Research Institute (protocol number: 796-3-12020).

\section{Semen processing}

After evaluation, the fresh semen samples were pooled and then split into five equal fractions and diluted at $30{ }^{\circ} \mathrm{C}$ with Tris-based extender alone (control) or supplemented with different concentrations of Spirulina extract $(1,5,10$ and $20 \mu \mathrm{g} / \mathrm{mL})$. The fresh semen samples were transferred to pre warmed tubes. Diluted semen was cooled from $37^{\circ} \mathrm{C}$ to $5{ }^{\circ} \mathrm{C}$ throughout $60 \mathrm{~min}$ in a cold cabinet. The cooled semen was loaded into $0.25 \mathrm{~mL}$ polyvinyl chloride straws (IMV, L'Aigle, France), horizontally placed in a refrigerator and kept at $4{ }^{\circ} \mathrm{C}$ for $1 \mathrm{~h}$ for equilibration. Straws were then placed $6 \mathrm{~cm}$ above the liquid nitrogen surface where the temperature was approximately $-120^{\circ} \mathrm{C}$. After $15 \mathrm{~min}$, straws were immersed directly into liquid nitrogen $\left(-196^{\circ} \mathrm{C}\right)$ for storage. The straws were stored at least for 24 hour before evaluation. Straws were thawed in water bath at $37^{\circ} \mathrm{C}$ for $30 \mathrm{sec}$.

\section{Assessment of post-thawing sperm motility}

Post-thawing sperm motility was assessed according to (Badr et al., 2010). Inbrief, The percentage of linear motile sperm was examined visually; three straws were thawed separately by immersion in a water bath at $37^{\circ} \mathrm{C}$ for $30 \mathrm{sec}$, samples were placed on glass slides covered with a cover and then estimated at $37^{\circ} \mathrm{C}$ by phase contrast microscope equipped with a warm stage at 200x magnification. Sperm motility estimation was performed in 3 different microscopic fields and the mean of them was recorded as the final motility score.

\section{Assessment of acrosomal integrity}

Acrosomal integrity was assessed following thawing using silver nitrate stain. Sperm suspension was spread over slides and dried at room temperature. The preparations were fixed in ethyl alcohol $70 \%$ for 2 min then in ethyl alcohol $95 \%$ for another 2 min. The preparations were stained with the silver nitrate solution $(100 \mathrm{mg} / 200 \mathrm{~mL}$ distilled water) for $2 \mathrm{~h}$ in an incubator at $65^{\circ} \mathrm{C}$. After the preparations were turned gold in color, the chemical reaction was interrupted and the preparations were rinsed several times with distilled water. The preparations were dried at room temperature. The dried preparations were analyzed for acrosomal integrity using the Olympus BX50 light microscope with a 100-fold magnification. 
At least 300 sperm cells were counted per slide and the percent of acrosome intact spermatozoa was calculated (El-Amrawi, 1992; El-Shahat et al., 2020).

\section{Ultrastructure analysis of the cryopreserved spermatozoa}

The ultrastructure changes of the cryopreserved spermatozoa were evaluated by transmission electron microscopy (TEM). Five straws from each treatment were washed three times by centrifugation at $1000 \mathrm{~g}$ for $5 \mathrm{~min}$ using phosphate buffer saline (PBS). The frozenthawed sample was prefixed for 2-3 h with PBS containing 2\% glutaraldehyde, washed three times by centrifugation at $1000 \mathrm{~g}$ with PBS (pH 7.4) for 5 min at $4{ }^{\circ} \mathrm{C}$ and post-fixed in $1 \%$ osmium tetroxide for $1-2 \mathrm{~h}$ at $4{ }^{\circ} \mathrm{C}$ (Boonkusol et al., 2010). Spermatozoa were dehydrated in propylene oxide and embedded in epon resin. Ultrathin sections were cut using the Leica EM UC6 ultra microtome and stained with uranyl acetate and lead citrate. Randomly fields were examined by a transmission electronic microscope (JEOL-EM-100 S at TEM lab FA-CURP, Faculty of Agriculture, Cairo University -Research Park CURP). Images were captured by CCD camera model AMT, optronics camera with 1632 × 1632 pixel format as side mount configuration.

\section{Biochemical assays of superoxide dismutase (SOD), Glutathione reductase (GSH), Malondialdehyde (MDA) and Total Antioxidant Capacity (TAC)}

SOD activity of frozen-thawed samples was measured at $560 \mathrm{~nm}$ on a spectrophotometer and expressed as units per milliliter according to Flohe and Otting (1984). Briefly, the increase in absorbance at $560 \mathrm{~nm}$ for 5 mint for control and for sample at $25^{\circ} \mathrm{C}$ was measured. SOD activity $(\mathrm{U} / \mathrm{mL})=\%$ inhibition $\times 3.75$. the assay is depending on the ability of SOD to prevent the reduction of nitroblue tetrazoliumdye.

GSH content was measured at $412 \mathrm{~nm}$ on a spectrophotometer and the values of GSH were expressed as units (Sedlak and Lindsay, 1968). Glutathione reductase activity $(\mathrm{U} / \mathrm{mL})=4019 \times 340 \mathrm{~nm} / \mathrm{min}$.

The concentrations of Malondialdehyde (MDA), as indices of the lipid peroxidation in the semen samples were measured using the thiobarbituric acid reaction according to the method of Placer et al. (1966). In brief, an aliquot of semen sample $(500 \mu \mathrm{L})$ was centrifuged at $800 \mathrm{xg}$ for ten minutes, sperm pellets were gathered and resuspended in phosphate buffer saline then recentrifuged again, after centrifugation, $1 \mathrm{~mL}$ of deionized water was added to sperm followed by snap-freezing and store at -70 until usage. Malondialdehyde $\left(\mathrm{nmol} / 10^{9}\right)=\mathrm{A}$ Sample/A Standard $\times 10$

TAC content was measured at $505 \mathrm{~nm}$ on a spectrophotometer and the values of TAC were expressed as $\mathrm{mM} / \mathrm{L}$ according to Kumar et al. (2017). Determination of tac was accomplished by the reaction of antioxidants of the sample with a definite amount of exogenouly added hydrogen peroxide. Tac $(\mathrm{mM} / \mathrm{L})=$ absorbance of blank - absorbance of sample $\times 3.33$

\section{Artificial insemination of the synchronized buffaloes}

Estrus was synchronized in normal cyclic buffaloes $(n=62)$ as mentioned by Hoque et al. (2011). In brief, at day (0); $5 \mathrm{~mL}$ buserelin; a synthetic analogue of GnRH (Receptal) ${ }^{\mathrm{R}} /$ buffalo was injected, at day (7); $2 \mathrm{~mL}$ cloprostenol; a synthetic analogue of PGF2a (Estrumate) ${ }^{\mathrm{R}}$ /buffalo was injected, at day (9); $5 \mathrm{~mL}$ receptal/ buffalo was injected, at day (10); artificial insemination was done by recto-cervical technique using frozen-thawed straw with $15 \times 10^{6}$ spermatozoa. Insemination was done twice (AM and PM) for each buffalo, insemination was done in winter season, only cryopreserved semen with $10 \mu \mathrm{g} / \mathrm{mL} \mathrm{SPE}$ and the control were used for Al trials, pregnancy was checked at day 35 using 7.5-10 MHz - linear-array transducer attached with ultrasound machine (Sonoscape A5, China). 


\section{Statistical analysis}

Experiments were repeated three times. data were analyzed by using Costat Computer Program, Version 3.03 copyright Cottort Software, and were compared by the least significant difference least (LSD) at $5 \%$ level of probability. The results were expressed as mean \pm SEM. The mean values of the percentages of motile sperm, acrosome-intact sperm and enzymes activity were compared using Duncan's multiple range test by one-way ANOVA procedure . Conception rates were compared using Student t-test, F-value was significant at $(P<0.05)$.

\section{Results}

\section{Effect of SPE addition to semen extender on semen freezability}

The results presented in Table 1 revealed that, addition of SPE to the freezing extender improved the freezability of buffalo bull spermatozoa compared with the control in dose dependent manner. The results obtained in the sample supplemented with $10 \mu \mathrm{g} / \mathrm{mL}$ of SPE were the highest of all tested samples and differed significantly compared with the control group. Addition of $10 \mu \mathrm{g} / \mathrm{mL}$ SPE significantly $(P<0.05)$ improved post-thawing sperm motility and decreased the percentage of damaged acrosome $(51.67 \pm 6.02 \%$ and $16.33 \pm 1.46 \%$, respectively) compared with the control $(28.33 \pm 4.41 \%$ and $26.33 \pm 1.77 \%$, respectively) and $20 \mu \mathrm{g} / \mathrm{mL}$ (30.00 $\pm 5.01 \%$ and $29.33 \pm 3.18 \%$, respectively) (Figure 1).

Table 1. Effect of Spirulina platensis extract (SPE) addition to semen extender on buffalo bull semen freezability.

\begin{tabular}{ccc} 
Treatment & Post-thawing motility (\%) & Acrosomol abnormality (\%) \\
\hline Control & $28.33 \pm 4.41^{\mathrm{c}}$ & $26.33 \pm 1.77^{\mathrm{ab}}$ \\
\hline SPE $\mathbf{\mu g} / \mathbf{m L}$ & $36.67 \pm 4.40^{\mathrm{abc}}$ & $19.00 \pm 2.09^{\mathrm{bc}}$ \\
\hline SPE $\mathbf{5} \boldsymbol{\mu g} / \mathbf{m L}$ & $45.00 \pm 2.89^{\mathrm{ab}}$ & $20.33 \pm 2.91^{\mathrm{bc}}$ \\
\hline SPE $\mathbf{1 0} \boldsymbol{\mu \mathrm { g } / \mathrm { mL }}$ & $51.67 \pm 6.02^{\mathrm{a}}$ & $16.33 \pm 1.46^{\mathrm{c}}$ \\
\hline SPE $\mathbf{2 0} \boldsymbol{\mu g} / \mathrm{mL}$ & $30.00 \pm 5.01^{\mathrm{bc}}$ & $29.33 \pm 3.18^{\mathrm{a}}$ \\
\hline
\end{tabular}

Values with different superscripts within the same columns differed significantly at $(\mathrm{P}<0.05)$.

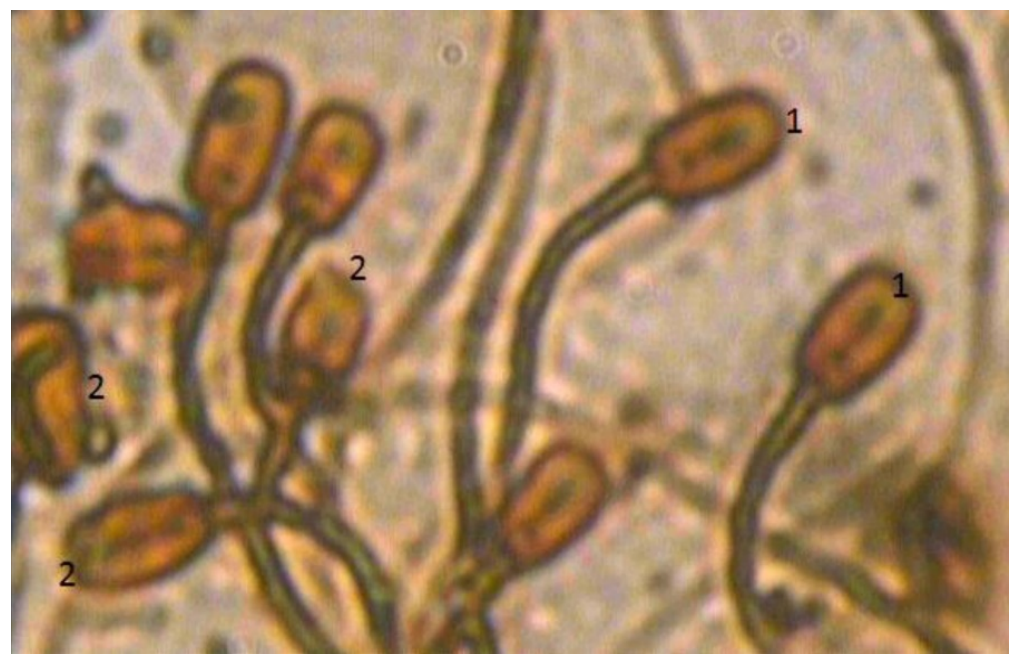

Figure 1. Silver nitrate staining of sperm acrosomes with magnification of $(\times 100), 1$ refers to normal acrosome while 2 refers to damaged acrosome. 


\section{Effect of SPE addition to semen extender on antioxidant activity of the cryopreserved semen and lipid peroxidation}

Data regarding the effect of SPE addition to the freezing extender on the total antioxidant capacity (TAC), SOD, GSH activities and lipid peroxidation of the cryopreserved buffalo bull spermatozoa were presented in Table 2. Supplementation of freezing extender with $10 \mu \mathrm{g} / \mathrm{mL}$ SPE significantly $(P<0.05)$ increased TAC, SOD and GSH concentrations $(0.49 \pm 0.014$, $58.33 \pm 1.76$ and $61.66 \pm 2.02)$ compared with the control $(0.30 \pm 0.049,33.66 \pm 3.29$ and $40.66 \pm 1.46$, respectively). Whereas, the present data demonstrated that, in vitro provision of semen extender with $10 \mu \mathrm{g} / \mathrm{mL}$ SPE significantly $(P<0.05)$ diminished lipid peroxidation of the frozen-thawed semen $\left(10.66 \pm 2.40 \mathrm{nmol} / 10^{9}\right)$ compared with the control $\left(22.66 \pm 4.26 \mathrm{nmol} / 10^{9}\right)$.

Table 2. Effect of SPE addition to semen extender on anti-oxidant activities and lipid peroxidation of cryopreserved buffalo bull spermatozoa.

\begin{tabular}{cccc|c} 
Treatment & $\begin{array}{c}\text { TAC } \\
(\mathbf{m M / L})\end{array}$ & $\begin{array}{c}\text { SOD } \\
(\mathbf{U} / \mathbf{m L})\end{array}$ & $\begin{array}{c}\text { GSH } \\
(\mathbf{U} / \mathbf{m L})\end{array}$ & $\begin{array}{c}\text { Lipid peroxidation } \\
\left(\mathbf{n m o l} / \mathbf{1 0}^{\mathbf{9}}\right)\end{array}$ \\
\hline Control & $0.30 \pm 0.049^{\mathrm{b}}$ & $33.66 \pm 3.29^{\mathrm{c}}$ & $40.66 \pm 1.46^{\mathrm{c}}$ & $22.66 \pm 4.26^{\mathrm{a}}$ \\
\hline SPE $\mathbf{\mu g} / \mathbf{m L}$ & $0.38 \pm 0.042^{\mathrm{ab}}$ & $43.66 \pm 4.91^{\mathrm{bc}}$ & $51.33 \pm 4.98^{\mathrm{abc}}$ & $16.33 \pm 2.03^{\mathrm{ab}}$ \\
\hline SPE $\mathbf{5} \boldsymbol{\mu g} / \mathbf{m L}$ & $0.40 \pm 0.052^{\mathrm{ab}}$ & $51.33 \pm 4.34^{\mathrm{ab}}$ & $56.00 \pm 4.59^{\mathrm{ab}}$ & $14.33 \pm 2.61^{\mathrm{ab}}$ \\
\hline SPE $\mathbf{1 0} \boldsymbol{\mu g} / \mathbf{m L}$ & $0.49 \pm 0.014^{\mathrm{a}}$ & $58.33 \pm 1.76^{\mathrm{a}}$ & $61.66 \pm 2.02^{\mathrm{a}}$ & $10.66 \pm 2.40^{\mathrm{b}}$ \\
\hline SPE $\mathbf{2 0} \boldsymbol{\mu g} / \mathbf{m L}$ & $0.32 \pm 0.018^{\mathrm{b}}$ & $38.66 \pm 5.05^{\mathrm{bc}}$ & $47.00 \pm 2.65^{\mathrm{bc}}$ & $24.00 \pm 4.05^{\mathrm{a}}$ \\
\hline
\end{tabular}

Values with different superscripts in the same columns were significantly different at $(\mathrm{P}<0.05)$. TAC: total antioxidant capacity; SOD: superoxide dismutase; GSH: glutathione reductase.

\section{Effect of SPE addition to semen extender on fine structure of the cryopreserved spermatozoa}

Frozen-thawed spermatozoa in the control group showed, swollen plasma membrane segmentation of the outer acrosomal membrane and swollen acrosome, moreover, severe degeneration and marked vacuolation in the mitochondria with complete absence of the transverse cristae (Figure $2 \mathrm{a}$ and $2 \mathrm{~b}$ ). Electron microscopic images of sagital sections of the frozen thawed sperm cells treated with $10 \mu \mathrm{g} / \mathrm{mL}$ SPE illustrated a well defined and intact plasma membrane, intact acrosomal membranes, homogenous mitochondria and high-quality mitochondrial dense electron spaces with appeared transverse cristae (Figure 3a and 3b).

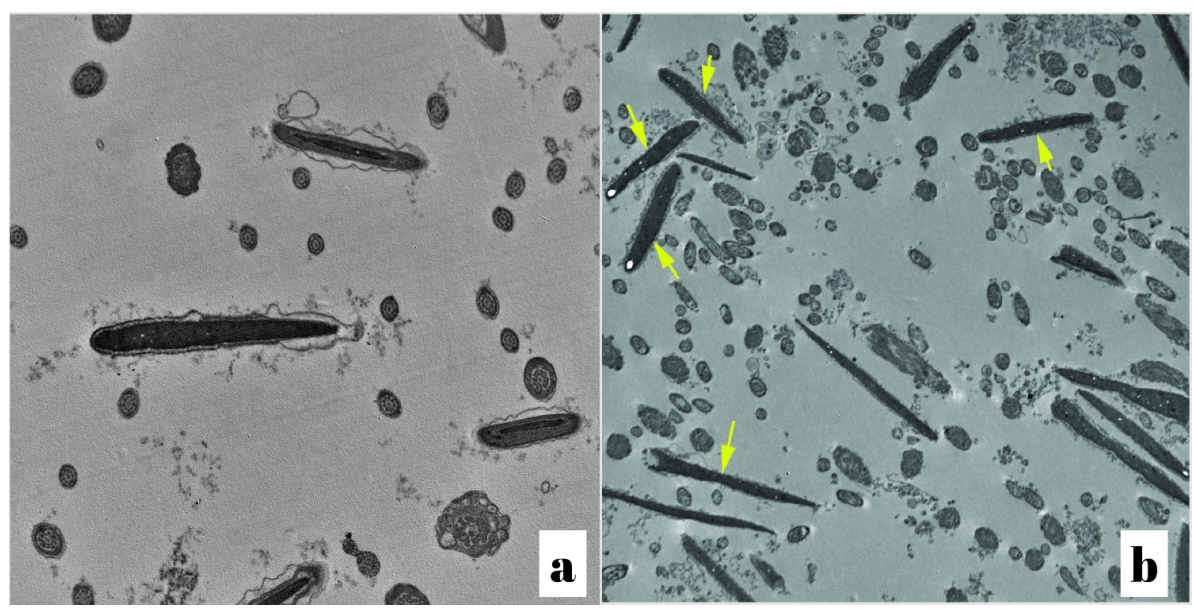

Figure 2. (a) Electron micrograph for a sagital section in the sperm head from a frozen-thawed semen sample of control group showing swollen plasma membrane (PM) (× 15000); (b) Electron micrograph for a sagital section in the sperm head from frozen-thawed semen sample treated with spirulina illustrating intact plasma membrane (PM) and the outer and inner acrosomal membranes are intact and the subacrosomal space is evident $(\times 15000)$, as referred by yellow arrows. 


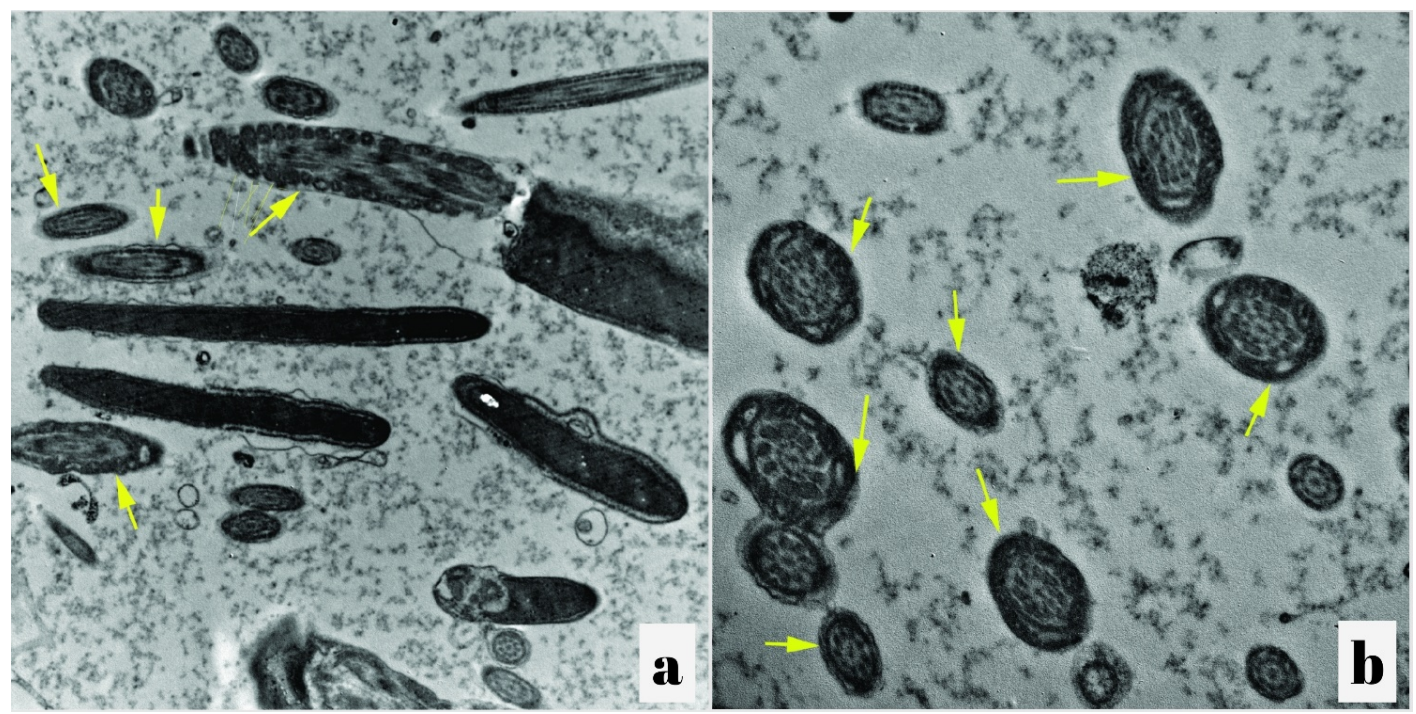

Figure 3. (a) Electron micrograph of a cross section in the neck region (note the presence of mitochondria in different orientation) of sperm from a frozen-thawed semen sample of control group showing severe degeneration (marked vacuolation) in the mitochondria that contained electrontranslucent spaces with complete absence of the transverse cristae and some mitochondria are completely disappeared ( $\times 30000)$ as referred by yellow arrows; (b) Electron micrograph of a cross section in the mid-piece region of the tail from a frozen-thawed semen sample treated with spirulina illustrating good mitochondrial dense electron spaces with appeared transverse cristae $(\times 30000)$ as referred by yellow arrows.

\section{Effect of SPE addition to semen extender on fertility following post-thawing artificial insemination}

As shown in Table 3, the conception rate was significantly $(P<0.05)$ higher following artificial insemination of the synchronized buffaloes with frozen-thawed semen samples supplemented with $10 \mu \mathrm{g} / \mathrm{mL}$ SPE $(62.50 \pm 1.72 \%)$ compared with the control $(26.67 \pm 1.26 \%)$.

Table 3. Effect of SPE addition to semen extender on conception rate following artificial insemination.

\begin{tabular}{cccc} 
Treatment & No of buffalo & No of conceived buffalo & Conception rate \\
\hline control & 30 & 8 & $26.67 \pm 1.26^{\mathrm{b}}$ \\
\hline SPE $\mathbf{1 0} \boldsymbol{\mu g} / \mathrm{mL}$ & 32 & 20 & $62.50 \pm 1.72^{\mathrm{a}}$ \\
\hline
\end{tabular}

Values with different superscript in the same columns were significantly different at $(\mathrm{P}<0.05)$.

\section{Discussion}

The goal of cryopreservation is to be able to preserve the quality of spermatozoa for long term, but there are several factors that could affect the post-thawing outcomes (Azevedo, 2006). One of the most important factors is the extender constituents. Supplementation of the freezing extender with SPE was significantly enhancing the characteristics of the cryopreserved buffalo spermatozoa, such as progressive motility, acrosome integrity, antioxidant activity, moreover reducing lipid peroxidation and preserve the fertilizing potential of the cryopreserved spermatozoa, in a dose dependent manner, while with increasing dose to $20 \mu \mathrm{g} / \mathrm{mL}$, a decline in sperm quality may be observed. The limitation of this study was the small sample size.

The results were in line with the findings of (Kistanova et al., 2009; Nah et al., 2012; ElTantawy, 2016; Djalil et al., 2019; Mizera et al., 2019). The previous authors reported the positive effects of SPE on motility, antioxidant activity and membrane integrity of mammalian spermatozoa. Moreover, (Granaci, 2007b; Mizera et al., 2019) reported that biological extract of Spirulina has a positive effect on sperm motility and viability after storage. In the same way of our results (Mizera et al., 2019) reported a significant incresea in motility percentage of 
bovine sperm from $49.36 \%$ in control group to $61.23 \%$ in spirulina treated group. Additionally, Spirulina supplementation also has an optimistic outcome on the process of spermatogenesis in rats (Nah et al., 2012; Esener et al., 2017).

Spirulina contains vital compounds, such as protein $(50-70 \%$ on DM basis) with all essential amino acids (Farag et al., 2016), essential fatty acids, alpha-linolenic, gammalinolenic and linoleic (Mendes et al., 2003), nutraceutical pigments (Keservani et al., 2015), vitamins as thiamine, nicotinamide, riboflavin, folic acid, pyridoxine, vitamins $A, D$ and $E$ (Hosseini et al., 2013) and minerals like $\mathrm{Ca}, \mathrm{K}, \mathrm{Cr}, \mathrm{Cu}, \mathrm{Mn}, \mathrm{Fe}, \mathrm{P}, \mathrm{Mg}, \mathrm{Na}, \mathrm{Zn}$ and $\mathrm{Se}$ (Babadzhanov et al., 2004).

It is also known Spirulina has an antioxidant potential (El-Tantawy, 2016) and anti-diabetic effects as it plays a crucial role in decreasing blood glucose level, regulating cholesterol and improving insulin resistance (Gupta et al., 2010).

A variety of speculations have been proposed by several authors to explain the protective mechanism of SPE on mammalian spermatozoa. The beneficial effect of SPE may be due to its anti-inflammatory activity (Cingi et al., 2008). Rahman et al. (2012) reported that Spirulina may increase the production of both immunostimulatory and immuno-mediators. Moreover, many reports recorded the significant effect of Spirulina as free radicals scavenging. Our results had been confirmed the antioxidant activities of spirulina, moreover its crucial role in decreasing the lipid peroxidation. Another theory for the beneficial effects of SPE on the vital parameters of the cryopresreved spermatozoa may be attributed in fact to its antioxidant activities, scavenge ROS and protect sperm cell from toxic oxygen metabolites causing lipid peroxidation of sperm plasma membrane during cryopreservation (Bilodeau et al., 2001). Antonio Marcos et al. (2018) reported that the addition of C-phycocyanin as an extracted compound from Arthrospira maxima in the boar semen extender could control the production of intracellular ROS production that couldy positively reflect on the increase in the percentage of progressive motility.

Membrane of mammalian spermatozoa is sensitive to oxygen-induced damage; excessive formation of either ROS or Reactive Nitrogen Species (RNS) by abnormal spermatozoa has been identified as one of the few definite reasons for male infertility. Oxidative stress is a condition associated with an increased rate of cellular damage induced by oxygen and oxygen-derived oxidants (Sikka et al., 1995), that have been implicated in impaired semen quality (Joyce, 1987). Mammalian spermatozoa are susceptible to lipid peroxidation which destroys the structure of the lipid matrix of plasma membrane, due to the attacks of ROS formed from reduction of oxygen during cryopreservation. The damage of lipid matrix finally causes irreversible damage to the plasma membrane, decreased sperm motility, loss of fertility and damage of the sperm DNA (Storey, 2008). The current data confirms this theory as SPE supplementation increased the activity of antioxidant enzymes and reduced lipid peroxidation of the cryopreserved spermatozoa compared with the control. Similar antioxidant potential of Spirulina has been observed (Gutiérrez-Rebolledo et al., 2015; Asghari et al., 2016; Bashandy et al., 2016).

The present results revealed a significant higher conception rate in the artificially inseminated buffaloes with frozen-thawed semen supplemented with $10 \mu \mathrm{g} / \mathrm{mL}$ SPE, this may be attributed to the valuable effects of SPE on acrosomal integrity, decrease lipid peroxidation, enhancing the membrane integrity and antioxidant activities of the cryopreserved spermatozoa that would eventually enhance the fertilizing potentials of the cryopresreved spermatozoa.

Results of the current study confirmed that increasing of the used SPE to $20 \mu \mathrm{g} / \mathrm{mL}$ was detrimental to the cryopreserved buffalo bull spermatozoa. In agreement with this finding (Mizera et al., 2019) reported that, high concentrations of SPE could lead to a significant reduction in sperm motility and viability. 


\section{Conclusion}

The emerged results of this study clearly demonstrate that supplementation of semen extender with SPE exerts valuable effects on the quality and the fertilizing potentials of the cryopreserved buffalo spermatozoa in a dose dependent manner. $10 \mu \mathrm{g} / \mathrm{mL}$ SPE addition appeared to be the best concentration. These beneficial effects appeared due to the improvement of the antioxidant activities and the diminishing rates of lipid peroxidation of the cryopreserved spermatozoa.

\section{References}

Abd El-Baky HH, El-Baz FK, El-Baroty GS. Enhancement of antioxidant production in Spirulina platensis under oxidative stress. American- Eurasian J. Sci. Res. 2007;2:170-9.

Abshenas J, Babaei H, Zare MH, Allahbakshi A, Sharififar F. The effect of green tea (Camellia sinensis) extract on mouse semen quality after scrotal heat stress. Vet Res Forum. 2011;4:242-7.

Aitken RJ, Ryan AL, Baker MA, McLaughlin EA. Redox activity associated with the maturation and capacitation of mammalian spermatozoa. Free Radic Biol Med. 2004;36(8):994-1010. http://dx.doi.org/10.1016/j.freeradbiomed.2004.01.017. PMid:15059640.

Aitken RJ. Reactive oxygen species as mediators of sperm capacitation and pathological damage. Mol Reprod Dev. 2017;84(10):1039-52. http://dx.doi.org/10.1002/mrd.22871. PMid:28749007.

Alvarez JG, Storey BT. Spontaneous lipid peroxidation in rabbit epididymal spermatozoa: its effect on sperm motility. Biol Reprod. 1982;27(5):1102-8. http://dx.doi.org/10.1095/biolreprod27.5.1102. PMid:6297627.

Antonio Marcos EG, Monroy Hermosillo O, Cortes Barberena E, Rodriguez Tobon E, Rivera Martinez JG, Arenas Rios E. Can C-phycocyanin be used as a sperm protector? Veterinaria Mexico OA. 2018;5(4):19.

Asghari A, Fazilati M, Latifi AM, Salavati H, Choopani A. Antioxidant properties of Spirulina. J Appl Biotechnol Rep. 2016;3:345-51.

Azevedo HC. (2006). Spermatic integrity and function in RAM cryopreserved sêmen after incorporation of cholesterol, desmosterol, oleic-linoleic acid and -lactalbumin [thesis]. Botucatu: Faculty of Veterinary Medicine and Animal Science, UNESP.

Babadzhanov AS, Abdusamatova N, Yusupova FM, Faizullaeva N, Mezhlumyan LG, Malikova MK. Chemical composition of Spirulina platensis cultivated in Uzbekistan. Chem Nat Compd. 2004;40(3):276-9. http://dx.doi.org/10.1023/B:CONC.0000039141.98247.e8.

Badr MR, El-Malak MJA, Hassan HM. Effect of trehalose on cryopreservation, oxidative stress and DNA integrity of buffalo spermatozoa. J Reprod Infertil. 2010;2:50-7.

Baruselli PS, Carvalho NAT, Gimenes LU, Crepaldi GA. Fixed-time artificial insemination in buffalo. Ital J Anim Sci. 2007;6:107-18.

Bashandy S, Mohamed M, Fatma A. Spirulina platensis, reduced liver and kidney injuries induced by sodium arsenite. Int J Pharm Tech Res. 2016;11:35-48.

Bilodeau JF, Blanchette S, Gagnon C, Sirard MA. Thiols prevent H O - mediated loss of sperm motility in cryopresreved bull semen. Theriogenology. 2001;56(2):275-86. http://dx.doi.org/10.1016/S0093691X(01)00562-3. PMid:11480619.

Boonkusol D, Saikhun K, Ratanaphumma P. Effect of extender and storage time on motility and ultrastructure of cooled-preserved boar spermatozoa. Witthayasan Kasetsat Witthayasat. 2010;44:582-9.

Bucak MN, Sariozkan S, Tuncer PB, Ulutas PA, Akcadag HAA. Effect of antioxidants on microscopic semen parameter, lipidperoxidation and antioxidant activities in Angora goat semen following cryopreservation. Small Rumin Res. 2009;81(2-3):90-5. http://dx.doi.org/10.1016/j.smallrumres.2008.11.011.

Calamera JC, Fernandez PJ, Buffone MG, Acosta AA, Doncel GF. Effects of long-term in vitro incubation of human spermatozoa: functional parameters and catalase effect. Andrologia. 2001;33(2):79-86. http://dx.doi.org/10.1046/j.1439-0272.2001.00409.x. PMid:11350371.

Chu W, Lim Y, Radhakrishnan AK, Lim PE. Protective effect of aqueous extract from Spirulina platensis against cell death induced by free radicals. BMC Complement Altern Med. 2010;10(1):53. http://dx.doi.org/10.1186/1472-6882-10-53. PMid:20858231. 
Cingi C, Conk-Dalay M, Cakli H, Bal C. The efects of Spirulina on allergic rhinitis. Eur Arch Otorhinolaryngol. 2008;265(10):1219-23. http://dx.doi.org/10.1007/s00405-008-0642-8. PMid:18343939.

Djalil OIA, Ngoula Ferdinand N, Adoum IY, Tchoffo Herve T, Djalal AK, Vemo BN, Herman NV. Effects of hydro-ethanolic extract of Spirulina (Spirulina platensis) on semen characteristics and oxidative stress indicators in male rabbit (Oryctolagus cuniculus). J Vet Med Animal Sci. 2019;2(1):1010.

El-Amrawi GA. Study on capacitation of buffalo spermatozoa. In: Egyptian Society Animal Reproduction Fertility 3rd Annual Congress; 1992; Cairo. Cairo: ESARF; 1992. p. 214-22.

El-Ratel IT, Gabr AA. Potential impact of Spirulina Alga as an antioxidant on improving semen production and oxidative stress in blood and seminal plasma of rabbit bucks. Egypt Poult Sci J. 2020;40(1):20924. http://dx.doi.org/10.21608/epsj.2020.81017.

El-Shahat KH, Taysser MI, Badr MR, Zaki K. Investigating the effects of theophylline on motility, hyperactivity, and acrosome reaction of spermatozoa in rams. Veterinary Medicine and Public Health Journal. 2020;3:81-4. http://dx.doi.org/10.31559/VMPH2020.1.3.2.

El-Tantawy WH. Antioxidant effects of Spirulina supplement against lead acetate-induced hepatic injury in rats. J Tradit Complement Med. 2016;6(4):327-31. http://dx.doi.org/10.1016/j.jtcme.2015.02.001. PMid:27774414.

El-Tohamy MM, El-Nattat WS. Effect of antioxidant on lead-induced oxidative damage and reproductive dysfunction in male rabbits. J Am Sci. 2010;6:613-22.

Esener OBB, Gurel-Gurevin E, Isbilen-Basok B, Yigit F, Bilal T, Altiner A, Yilmazer N, Armutak El. Spirulina platensis affects factors involved in spermatogenesis and increases ghrelin receptors in testis tissue of rats fed a high-fat diet. Pol J Vet Sci. 2017;20(3):467-75. http://dx.doi.org/10.1515/pjvs-2017-0056. PMid:29166288.

Farag MR, Alagawany M, Abd El-Hac ME, Dhama K. Nutritional and healthical aspects of Spirulina (Arthrospira) for poultry, animals and human. Int J Pharmacol. 2016;12(1):36-51. http://dx.doi.org/10.3923/ijp.2016.36.51.

Farber JL, Kyle ME, Coleman JB. Mechanisms of cell injury by activated oxygen species. Lab Invest. 1990;62(6):670-9. PMid:2162996.

Flohé L, Otting F. Superoxide dismutase assays. Methods Enzymol. 1984;105:93-104. http://dx.doi.org/10.1016/S0076-6879(84)05013-8. PMid:6328209.

Ford WCL. Regulation of sperm function by reactive oxygen species. Hum Reprod Update. 2004;10(5):387-99. http://dx.doi.org/10.1093/humupd/dmh034. PMid:15218008.

Fouda S, Ismail R. Effect of Spirulina Platensis on reproductive performance of rabbit bucks. Egypt J Nutr Feeds. 2017;20(1):55-66. http://dx.doi.org/10.21608/ejnf.2017.75118.

Granaci V. Achievements in the artificial insemination of swine. Bull Univ Agric Sci Vet Med Cluj-Napoca Anim Sci Biotechnol. 2007a;63/64:382-6.

Granaci V. Contributions on the study of the cryoresistance increase of the bull semen material. Bull Univ Agric Sci Vet Med Cluj-Napoca Anim Sci Biotechnol. 2007b;63/64:387-91.

Gupta S, Hrishikeshvan HJ, Sehajpal PK. Spirulina protects against rosiglitazone induced osteoporosis in insulin resistance rats. Diabetes Res Clin Pract. 2010;87(1):38-43. http://dx.doi.org/10.1016/j.diabres.2009.10.002. PMid:19896232.

Gutiérrez-Rebolledo GA, Galar-Martínez M, Garcia-Rodriguez RV, Chamorro-Cevallos GA, HernándezReyes AG, Martinez-Galero E. Antioxidant effect of Spirulina (Arthrospira) maxima on chronic inflammation induced by Freund's complete adjuvant in rats. J Med Food. 2015;18(8):865-71. http://dx.doi.org/10.1089/jmf.2014.0117. PMid:25599112.

Hoque MN, Talukdar AK, Kamal M, Kumar AJ, Farida YB, Shamsuddin M. Ovulation synchronization in water buffaloes guided by milk progesterone Elisa. J Embryo Transf. 2011;26:105-9.

Hosseini SM, Khosravi-Darani K, Mozafari MR. Nutritional and medical applications of Spirulina microalgae. Mini Rev Med Chem. 2013;13(8):1231-7. http://dx.doi.org/10.2174/1389557511313080009. PMid:23544470.

Joyce DA. Oxygen radicals in disease. Adverse Drug React Bull. 1987;127(1):476-9. http://dx.doi.org/10.1097/00012995-198712000-00001. 
Keservani RK, Kesharwani RK, Sharma AK, Jarouliya U. Dietary supplements, nutraceutical, and functional foods in immune response (immunomodulators). In: Bagchi D, Preuss HG, Swaroop A, editors. Nutraceutical and functional foods in human life and disease prevention. Boca Raton: CRC Press, Taylor and Francis; 2015. chap. 20, p. 343-60.

Khan Z, Bhadouria P, Bisen PS. Nutritional and therapeutic potential of Spirulina. Curr Pharm Biotechnol. 2005;6(5):373-9. http://dx.doi.org/10.2174/138920105774370607. PMid:16248810.

Kistanova E, Marchev Y, Nedeva R, Kacheva D, Shumkov K, Georgiev B, Shimkus A. Effect of the Spirulina platensis included in the main diet on the boar sperm quality. Biotechnol Anim Husb. 2009;25(5-61):547-57. http://dx.doi.org/10.2298/BAH0906547K.

Kumar P, Saini M, Kumar D, Bharadwaj A, Yadav PS. Estimation of endogenous levels of osteopontin, total antioxidant capacity and malondialdehyde in seminal plasma: application for fertility assessment in buffalo (Bubalus bubalis) bulls. Reprod Domest Anim. 2017;52(2):221-6. PMid:27862407.

Kurd F, Samavati V. Water soluble polysaccharides from Spirulina platensis: extraction and in vitro anticancer activity. Int J Biol Macromol. 2015;74:498-506. http://dx.doi.org/10.1016/j.ijbiomac.2015.01.005. PMid:25583023.

Leboeuf B, Restall B, Salamon S. Production and storage of goat semen for artificial insemination. Anim Reprod Sci. 2000;62(1-3):113-41. http://dx.doi.org/10.1016/S0378-4320(00)00156-1. PMid:10924822.

Medeiros CMO, Forell F, Oliveira ATD, Rodrigues JL. Current status of sperm cryopreservation: why isn't it better? Theriogenology. 2002;57(1):327-44. http://dx.doi.org/10.1016/S0093-691X(01)00674-4. PMid:11775978.

Mendes RL, Nobre BP, Cardoso MT, Pereira AP, Palavra AF. Supercritical carbon dioxide extraction of compounds with pharmaceutical importance from microalgae. Inorg Chim Acta. 2003;356:328-34. http://dx.doi.org/10.1016/S0020-1693(03)00363-3.

Mizera A, Kuczaj M, Szul A. Impact of the Spirulina maxima extract addition to semen extender on bovine sperm quality. Ital J Anim Sci. 2019;18(1):601-7. http://dx.doi.org/10.1080/1828051X.2018.1548914.

Nah WH, Koh IK, Ahn HS, Kim MJ, Kang H-G, Jun JH, Gye MC. Effect of Spirulina maxima on spermatogenesis and steroidogenesis in streptozotocin-induced type I diabetic male rats. Food Chem. 2012;134(1):173-9. http://dx.doi.org/10.1016/j.foodchem.2012.02.085.

Neild DM, Gadella BM, Chaves MG, Miragaya MH, Colenbrander B, Agüero A. Membrane changes during different stages of a freeze-thaw protocol for equine semen cryopreservation. Theriogenology. 2003;59(8):1693-705. http://dx.doi.org/10.1016/S0093-691X(02)01231-1. PMid:12566145.

Paul V, Prakash BS. Efficacy of the ovsynch protocol for synchronization of ovulation and fixed-time artificial insemination in Murrah buffaloes (Bubalus bubalis). Theriogenology. 2005;64(5):1049-60. http://dx.doi.org/10.1016/j.theriogenology.2005.02.004. PMid:16125551.

Placer ZA, Cushman LL, Johnson BC. Estimation of product of lipid peroxidation (malonyl dialdehyde) in biochemical systems. Anal Biochem. 1966;16(2):359-64. http://dx.doi.org/10.1016/00032697(66)90167-9. PMid:6007581.

Rahman MA, Moitry NF, Alam M, Yasmin Z, Debnath D, Mostofa M. Effects of Spirulina in lead induced toxicities in long evans rats. J Environ Sci Nat Resour. 2012;5(1):79-82. http://dx.doi.org/10.3329/jesnr.v5i1.11557.

Sedlak J, Lindsay RHC. Estimation of total, protein-bound and nonprotein sulfhydryl groups in tissue with Ellman's reagent. Anal Biochem. 1968;25(1):192-205. http://dx.doi.org/10.1016/0003-2697(68)900924. PMid:4973948.

Sikka SC, Rajasekaran M, Hellstrom WJ. Role of oxidative stress and antioxidants in male infertility. J Androl. 1995;16(6):464-8. PMid:8867595.

Storey B. Mammalian sperm metabolism:oxygen and sugar, friend and foe. Int J Dev Biol. 2008;52(56):427-37. http://dx.doi.org/10.1387/ijdb.072522bs. PMid:18649255.

Vemo BN, Kenfack A, Ngoula F, Akono Nantia E, Njieudeu Ngaleu CC, Nounamo Guiekep AJ, Megnimeza Tsambou AM, Nana Yidjeu F, Patrick Nelo C, Teguia A. Toxicity and reproductive parameter impairment of cypermethrin in male guinea pig (Cavia porcellus). Turkish J Agric-Food Sci Technol. 2018;6(2):130-5. http://dx.doi.org/10.24925/turjaf.v6i2.130-135.1408.

Vemo BN, Kenfack A, Ngoula F, Nantia EA, Kodjio N, Guiekep AJN, Tsambou AMM, Teguia A. Effects of ethanol extract of Bersama engleriana leaves on oxidative stress and reproductive parameters in male Guinea pig (Cavia porcellus) exposed to cypermethrin. Int J Biol Chem Sci. 2017;11(5):2243-53. http://dx.doi.org/10.4314/ijbcs.v11i5.23. 
Venkatachalam RN, Singh K, Marar T. Phytochemical screening and in vitro antioxidant activity of Psidium guajava. Free Rad Ant. 2012;2(1):31-6. http://dx.doi.org/10.5530/ax.2012.2.7.

\section{Author contributions}

MB: Supervision, editing, data analysis \& review; ZR: Editing, Conceptualization, original draft \& data analysis; AA: Formal analysis, methodology of sperm ultrastructure; RD: Editing, Conceptualization, original draft \& data analysis; TG: Editing, original draft \& data analysis; MF: Methodology, writing, review, data curation and analysis. 